\title{
Balancing carrots and sticks in REDD+: implications for social safeguards
}

\author{
$\underline{\text { Amy E. Duchelle }}^{1}$, Claudio de Sassi $^{1,2}$, Pamela Jagger $^{3}$, Marina Cromberg $^{1}, \underline{\text { Anne M. Larson }}^{4}$, William D. Sunderlin $^{1}, \underline{\text { Stibniati } S .}$ \\ Atmadja $^{5}$, Ida Aju Pradnja Resosudarmo ${ }^{1,6}$ and Christy Desta Pratama ${ }^{7}$
}

\begin{abstract}
Reducing carbon emissions through avoided deforestation and forest degradation and enhancement of carbon stocks (REDD+) is key to mitigating global climate change. The aim of REDD+ social safeguards is to ensure that REDD+ does not harm, and actually benefits, local people. To be eligible for results-based compensation through REDD+, countries should develop nationallevel safeguard information systems to monitor and report on the impacts of REDD+. Although safeguards represent a key step for promoting social responsibility in REDD + , they are challenging to operationalize and monitor. We analyzed the impacts of different types of REDD+ interventions (incentives vs. disincentives) on key safeguard-relevant indicators, i.e., tenure security, participation, and subjective well-being, as well as on reported forest clearing. We used household-level data collected in Brazil, Peru, Cameroon, Tanzania, Indonesia, and Vietnam from approximately 4000 households in 130 villages at two points in time (2010-2012 and 2013-2014). Our findings highlight a decrease in perceived tenure security and overall perceived well-being over time for households exposed to disincentives alone, with the addition of incentives helping to alleviate negative effects on well-being. In Brazil, although disincentives were associated with reduced reported forest clearing by smallholders, they were the intervention that most negatively affected perceived well-being, highlighting a clear trade-off between carbon and noncarbon benefits. Globally, although households exposed to REDD+ interventions were generally aware of local REDD+ initiatives, meaningful participation in initiative design and implementation lagged behind. Our analysis contributes to a relatively small literature that seeks to operationalize REDD+ social safeguards empirically and to evaluate the impacts of REDD+ interventions on local people and forests.
\end{abstract}

Key Words: climate change mitigation; livelihoods; monitoring; social impact assessment; well-being

\section{INTRODUCTION}

With the 2015 Paris Climate Agreement, the world agreed that mitigating the negative effects of climate change must include tropical forests. Deforestation and forest degradation produce $70 \%$ of tropical land-use emissions and account for $10-11 \%$ of net global greenhouse gas emissions (Le Quéré et al. 2015). Forests also serve as important carbon sinks, absorbing 4-6 gigatons (gt) of carbon from the atmosphere annually (IPCC 2014). Many tropical countries refer to reducing emissions from deforestation and forest degradation and enhancing carbon stocks (REDD+) in their nationally determined contributions (NDCs) toward keeping global temperature rise below $2.0 / 1.5^{\circ} \mathrm{C}$. Furthermore, over 300 subnational REDD+ initiatives have been implemented across the tropics (Simonet et al. 2015), enabling early action and enhancing learning through implementation on the ground (Sills et al. 2014). As part of the results-based financing aspect of REDD+, countries have put into place rigorous measurement, reporting, and verification (MRV) systems for assessing forest losses and gains relative to baseline or reference scenarios. In parallel, there is growing attention to establishing systems for monitoring the social impacts of REDD+. This new attention to social impacts is in sharp contrast to evaluations of early forest carbon projects, such as those implemented through the clean development mechanism, which gave very limited attention to whether projects were benefiting or harming local people (Caplow et al. 2011).

REDD+ safeguards, articulated by the United Nations Framework Convention on Climate Change (UNFCCC), are an important mechanism for providing guidance on monitoring and evaluating the potential social and environmental (or noncarbon) impacts of REDD+. The original concept of safeguards comes from multilateral development banks aiming to avoid, mitigate, or minimize adverse impacts from investment and development activities (World Bank 2005). The UNFCCC Cancun Agreement stipulates seven safeguards (Decision 1/CP.16) that encourage REDD+ programs to: (a) complement national forest programs and international conventions and agreements; (b) maintain transparent governance; (c) respect the knowledge and rights of indigenous people and local communities; (d) obtain effective participation in REDD+ design and implementation; (e) promote forest conservation and other environmental and social cobenefits; (f) address risks of reversals; and ( $\mathrm{g}$ ) reduce leakage (UNFCCC 2011). To be eligible for results-based finance through the UNFCCC, REDD+ countries should develop national-level safeguard information systems to monitor and regularly report on the social and environmental impacts of REDD+ (UNFCCC 2014). Furthermore, some multi- and bilateral donors and thirdparty certifiers require additional standards for demonstrating high social and environmental performance, such as the World Bank Forest Carbon Partnership Fund and the Climate Community and Biodiversity Alliance.

REDD+ performance can be achieved in different ways. Implementers of subnational REDD+ initiatives are applying intervention portfolios that combine strategies characterized as disincentives and incentives to achieve better protection and enhancement of forests (Sills et al. 2014). Indeed many of these initiatives reflect conventional integrated conservation and development approaches with conditional incentives playing a lesser role than originally envisaged (Sunderlin et al. 2015). Restrictions ("sticks") focus on strengthening compliance with

${ }^{1}$ Center for International Forestry Research (CIFOR), Bogor, Indonesia, ${ }^{2}$ Swiss Federal Office for the Environment, Bern, Switzerland, ${ }^{3}$ University of North Carolina at Chapel Hill, USA, ${ }^{4}$ Center for International Forestry Research (CIFOR), Lima, Peru, ${ }^{5}$ Center for International Forestry Research (CIFOR), Addis Ababa, Ethiopia, ${ }^{6}$ The Australian National University, Canberra, Australia, ${ }^{7}$ Conservation Strategy Fund, Jakarta, Indonesia 
Fig. 1. Study sites (map credit: Astrid Bos).

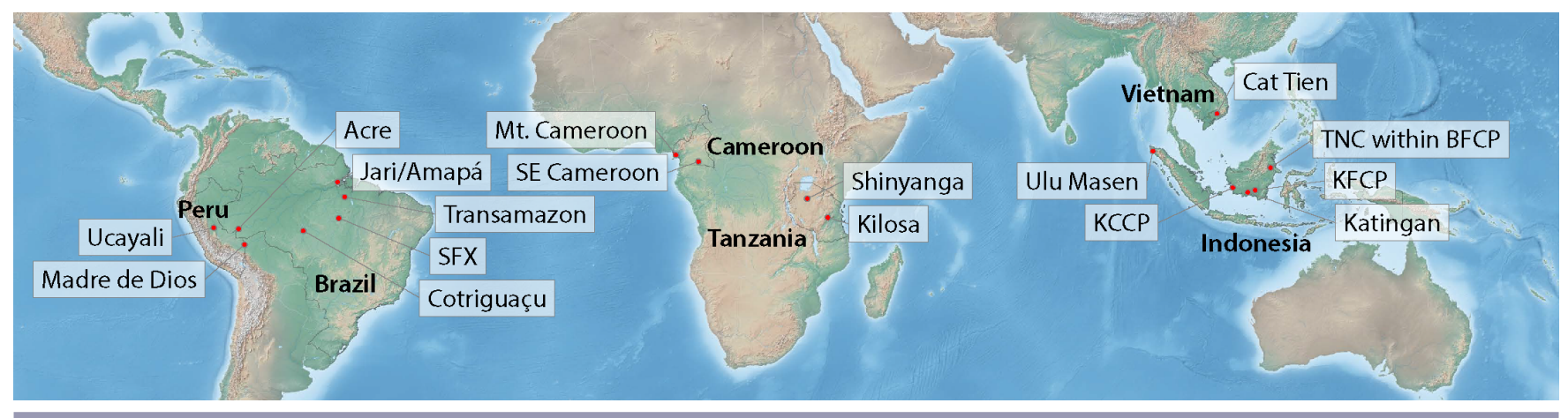

existing laws or norms, and include regulatory, monitoring, or enforcement activities that restrict access to or conversion of forests. Incentives ("carrots") include nonconditional or occasionally conditional livelihood enhancements (e.g., direct payments, subsidized or free agricultural inputs, technical assistance, etc.) to compensate landholders for expected losses, or even make them better off, for land management actions that favor REDD+ objectives. Prior to implementation of disincentives and incentives, enabling measures, such as land tenure clarification and environmental education, help establish the conditions for responsible land stewardship, e.g., in terms of adequate assignments of rights and information.

Our aim is to understand the impacts of different types of interventions designed to protect or enhance forests (i.e., incentives, disincentives, and a mixed portfolio of incentives and disincentives) on rural households in six tropical countries, using indicators of REDD+ social safeguards (c)-(e), which address rights, participation, and social benefits. We focus on these three safeguards because they are most relevant to local well-being and are those that are most appropriately evaluated, at least in part, at the household-level.

Specifically we ask the following questions:

1. What was the effect of different types of forest interventions on perceived tenure security, local awareness of and participation in REDD+, and perceived well-being?

2. How effective are the different types of interventions in reducing forest clearing?

The literature on rights, participation, and social cobenefits in REDD+ allowed us to operationalize the social safeguard indicators used in this analysis. For REDD+ safeguard (c), although respect for local knowledge and rights is quite broad, much of the REDD+ literature has converged on the importance of tenure security, or clear and enforceable local rights to forests and carbon (e.g., Corbera et al. 2011, Larson et al. 2013, Sunderlin et al. 2014). For safeguard (d), full and effective participation requires high levels of engagement by local stakeholders throughout REDD+ design and implementation. It begins with access to information, which is reflected in the requirement of free, prior, and informed consent (FPIC) as target communities choose whether to participate in REDD+. It also links to broader multilevel governance issues with mechanisms needed to promote local engagement in higher-level REDD+ processes (Agrawal et al. 2011). For safeguard (e), enhancement of other social benefits can be conceptualized as improving human well-being, assuring equitable benefit sharing, and increasing the adaptive capacity of local people (Lawlor 2013). Although narrow economic indicators (e.g., income) are often used to measure social benefits, subjective measures of human well-being are also needed (Woodhouse et al. 2015). Importantly, there are interconnections among these social dimensions; for instance, secure tenure can be considered the basis for improving local livelihoods and increasing local adaptive capacity (Chhatre et al. 2012), while greater local participation in REDD+ decision making may result in more equitable benefit sharing and long term support of the activities (Cromberg et al. 2014). In this context, it is critical to understand the impacts of different kinds of interventions, especially those that could inhibit local forest use, on household tenure security and well-being, and assess if people targeted by interventions are aware of and involved in local initiatives. Understanding local perceptions of the effects of interventions can provide a deeper understanding of the impacts of REDD+, and inform ways to design interventions to maximize benefits and minimize risks.

Our analysis contributes to a relatively small literature that seeks to operationalize REDD+ social safeguards empirically (e.g., Jagger and Rana 2017) and to evaluate the impact of forest interventions on local people (e.g., Sunderlin et al. 2017). Our focus on household-level impacts is novel, as is our use of data from a global comparative dataset. Our study design and its comparative nature provide considerable internal and external validity.

\section{METHODS}

\section{Study sites and sampling}

We use data gathered by the Center for International Forestry Research's (CIFOR) Global Comparative Study on REDD+ (http://www.cifor.org/gcs/) at 17 subnational REDD+ sites in Brazil, Peru, Cameroon, Tanzania, Indonesia, and Vietnam (Fig. 1). Sites were selected in early 2010 from among the population of subnational initiatives in the six countries that had defined site boundaries and intervention areas, but had not yet applied REDD+ interventions, allowing us to collect baseline data. Most of the initiatives were implemented by nongovernmental organizations, with the others led by for-profit companies or 
Table 1. Household-level data used to operationalize REDD+ social safeguards (c)-(e).

\begin{tabular}{lll}
\hline \hline Safeguard & Indicators & Data used \\
\hline (c) Rights & Tenure security & $\begin{array}{l}\text { Reported security of total household landholdings in phase } 1 \text { and } \\
\text { phase } 2(1=\text { secure, } 0=\text { insecure })\end{array}$ \\
(d) Participation & Knowledge of REDD+ initiative & $\begin{array}{l}\text { Household awareness of local REDD+ initiative in phase } 2(1= \\
\text { yes, } 0=\text { no })\end{array}$ \\
& Participation in REDD+ initiative & $\begin{array}{l}\text { Household involvement in design and/or implementation of local } \\
\text { REDD+ initiative in phase } 2(1=\text { yes, } 0=\text { no })\end{array}$ \\
& Subjective well-being & $\begin{array}{l}\text { Overall well-being of household in phase } 1 \text { and phase } 2 \text { compared } \\
\text { with two years prior }(1=\text { better off now, } 2=\text { about the same, } \\
\text { worse off now })\end{array}$ \\
& & $\begin{array}{l}\text { Perceived effect of specific interventions on household well-being } \\
\text { in phase } 2(1=\text { very negative, } 2=\text { negative, } 3=\text { no effect, } 4= \\
\text { positive, } 5=\text { very positive })\end{array}$ \\
\hline
\end{tabular}

subnational governments. The majority are dependent on public or philanthropic funding, and as of 2014, only 2 of the 17 had sold carbon credits (Sills et al. 2014). All initiatives were active during the period of our study, except for the Cat Tien project, which was discontinued in 2012 (Huynh 2014).

At these sites, we selected study villages and households based on a uniform sampling strategy, with 4 intervention (REDD+) and 4 control (non-REDD+) villages selected per site, and approximately 30 households randomly sampled per village. At six sites, there was some deviation from the target of four intervention and four control villages because of specific site-level constraints (e.g., at one site, there were only two villages in the REDD+ project area). More detail on the study sites, study design, and data collection is provided in Sills et al. (2014) and Sunderlin et al. (2016).

Baseline data (phase 1) were collected between 2010 and 2012. A second round of data (phase 2) was collected in 2013/2014. Both rounds of data collection involved semistructured interviews with village groups ( $\mathrm{N}=130$ in phase $1 ; \mathrm{N}=129$ in phase 2$)$ and a separate set of focus group interviews with women from each village $(\mathrm{N}=130$ in phase $1 ; \mathrm{N}=129$ in phase 2$)$. Household-level interviews were conducted in both research phases $(\mathrm{N}=4184$ in phase $1 ; \mathrm{N}=3989$ in phase 2).

During phase 2 of fieldwork, we collected data on all forest interventions that had been applied at the household level, including all interventions aimed at directly or indirectly influencing the way stakeholders use and manage local forests, whether applied by implementers of the REDD+ initiatives or not. To compile a full list of forest interventions for each study village, we used information from interviews with REDD+ implementers and village key informants, and revised the list based on information gathered in the village-level focus groups at the onset of fieldwork. In the household surveys, we then asked if the household had been involved in each intervention, and if so, their evaluation of its effect on their well-being. We categorized forest interventions into two main categories: (1) disincentives (sticks) that focus on restricting access to or conversion of forests and (2) incentives (carrots) that motivate forest-conserving actions through livelihood enhancements. Although we recognize the importance of enabling measures (e.g., tenure clarification and environmental education interventions) in promoting social safeguards, the low application of this type of intervention at our study sites limited our ability to include it as a separate category in the analyses.

Households in both REDD+ intervention and control villages were categorized according to whether they had received disincentives only, incentives only, a mixed portfolio of incentives and disincentives, or no interventions at all. We chose to categorize households in this way given that some key forest interventions (e.g. environmental fines) were not only applied at REDD+ sites, but rather more broadly across the landscape with clear implications for social safeguards. Also, households in REDD+ intervention villages were not treated homogeneously (i.e., there was within-village variation in the types of interventions applied), and many were involved in no interventions at all.

\section{Data analysis}

Assessing effects of forest interventions

We present household-level data on changes in tenure security, safeguard (c), knowledge of and participation in local REDD+ initiatives, safeguard (d), and subjective well-being, safeguard (e; Table 1). For the analysis of change in tenure security, we examined a change in reported tenure security of total household landholdings (forest and agricultural lands) between phase 1 and phase 2 among households exposed to different intervention types. In the household survey, tenure security was defined as the confidence that the household would continue to be able to use its current landholdings for at least the next 25 years.

For the analysis of knowledge and participation, we assessed awareness of, and participation in, the local REDD+ initiative in phase 2 among households at REDD+ sites that were exposed to different intervention types, including no interventions at all. Awareness was measured by asking respondents if they had heard of the local REDD+ initiative. Participation was measured by asking respondents if anyone in their household had been involved in any aspect of initiative design and/or implementation.

For the analysis of subjective well-being, we focused on two aspects of well-being in phase 2. The first focused on reported change in overall household well-being when compared with two years prior, and the second on the evaluation of the effect of specific interventions on household well-being. We used the broad Merriam-Webster (2010) definition of well-being, as "the state of being happy, healthy and prosperous" to avoid imposing a rigid 
definition on respondents' own conceptions of well-being (Sunderlin et al. 2016). For the first analysis, we looked at the proportion of households exposed to the different intervention types, including no interventions at all, that reported being better off and then at the proportion of those that reported being worse off in phases 1 and 2. For the second analysis, we calculated an average score from the Likert responses for the perceived effect of each intervention on household well-being in phase $2(1=$ very negative; $2=$ negative; $3=$ no effect $/$ both negative and positive; $4=$ positive; $5=$ very positive). When households were exposed to more than one intervention, we calculated a well-being change score for each by averaging the effect of different interventions first among those of the same type (e.g., all incentives) and then among different types of interventions (e.g., incentives and disincentives). Households that did not receive any interventions were excluded from this analysis because they did not report the effects of any interventions on their well-being.

We also present household-level data on reported forest clearing. For this analysis, we examined the change in reported forest clearing between phase 1 and phase 2 by households that were exposed to different intervention types, including no interventions at all. In both phases of the household survey, we asked respondents how much forest (ha) they had cleared in the two years prior to the survey. Because these values were self-reported, not objectively measured through remote sensing data, and smallholders may face sanctions for forest clearing, we hypothesize that some underreporting may have occurred.

\section{Statistical models}

For knowledge, participation and the effects of specific interventions on well-being, we were limited to using phase 2 data because those responses relied on households' assessment of specific interventions, which were only solicited in phase 2. For these analyses, the outcome of interest is the relative, pairwise difference between intervention types. We thus applied a Tukeystyle test for multiple comparison of parametric models, using the $g l h t$ function in the R multcomp package (Hothorn et al. 2008, $\mathrm{R}$ Core Team 2015), to rank intervention types according to the relative effect size. For tenure security, overall well-being (not linked to specific interventions), and forest clearing, we used the full set of data from phase 1 and phase 2, which enabled us to examine changes over time for households exposed to different intervention types.

We performed all analyses using mixed effects models in $\mathrm{R}$ package lme4 (Bates et. al 2015). In all models, we determined if changes in the social safeguard and forest clearing outcomes were affected by exposure to the different intervention types (i.e., disincentives only, incentives only, both disincentives and incentives, and no interventions at all). Models including both phase 1 and phase 2 data were fitted with phase, intervention type, and their interaction as fixed effects. We accounted for the hierarchical structure of the data, including village, study site, and country (the latter only for pooled sample models) as nested random effects. Models with a binary (yes/no) dependent variable, such as knowledge and participation, were fitted as logistic regressions. All models with a Gaussian error term were tested for overdispersion and fitted with an individual-level random effect as needed (Harrison 2014).

\section{RESULTS}

\section{Forest intervention types}

First, we present findings on the distribution of interventions by percent of households targeted by at least one intervention $(\mathrm{N}=$ 2007). At the global level (pooled results), incentives were the most common intervention applied: $40 \%$ alone and $27 \%$ as part of a mixed portfolio of incentives and disincentives (Fig. 2); disincentives accounted for the remaining 33\%. However, we observed considerable heterogeneity across countries. In Peru and Brazil, nearly half of targeted households were subjected to some sort of disincentive designed to restrict access to and/or conversion of forests. In contrast, in Indonesia, most households received only incentives, and at the REDD+ site studied in Vietnam only incentives were applied. At the Vietnam site, disincentives were intended to be part of the REDD+ implementation plan, but never happened because of the premature end of the project in 2012. Between 23 and $43 \%$ of targeted households in Peru, Brazil, Tanzania, and Cameroon received an intervention mix consisting of both disincentives and incentives. Of all households surveyed in phase $2(\mathrm{~N}=3989)$, about half received no interventions at all.

Fig. 2. Percent of targeted households in phase 2 that received incentives, disincentives, or both.

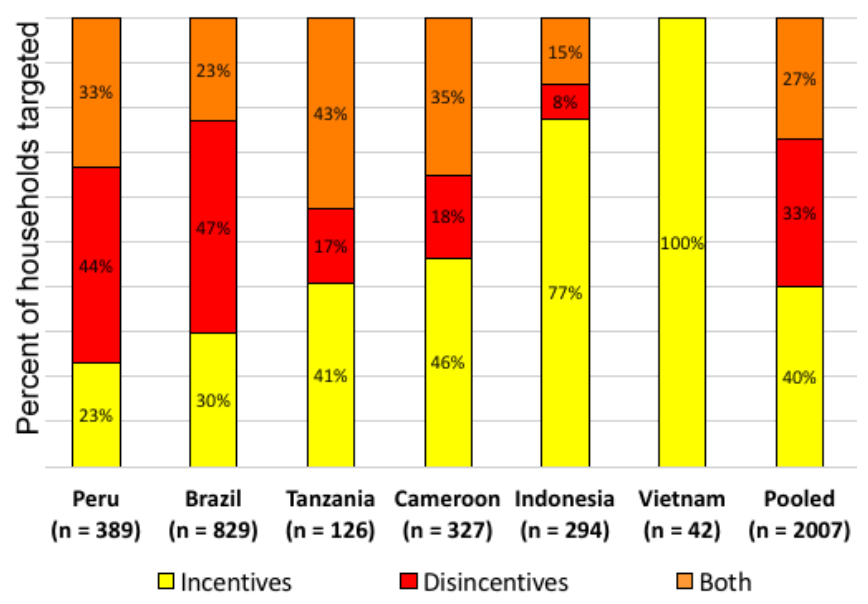

There were important differences between countries within the categories of disincentives and incentives. For disincentives, all interventions that restricted forest access and/or conversion were included in this category. Specific activities included determining the boundaries of set-aside forests, enforcing forest protection laws and regulations, and community monitoring (Table 2). At most sites in Brazil, disincentives primarily consisted of environmental fines and police patrols (including helicopter flyovers) by federal or state government agencies to dissuade smallholders from clearing and burning forests. Although these command-and-control measures were not implemented as part of the REDD+ initiatives, except in the case of Acre in which the state government led the program, they were key interventions aimed to reduce emissions from deforestation and forest degradation at the sites. At one site in Peru, disincentives included governmental land-use restrictions in Brazil nut concessions, 
Table 2. Examples of interventions in disincentive and incentive categories.

\begin{tabular}{ll}
\hline \hline $\begin{array}{l}\text { Intervention subcategories } \\
\text { Disincentives } \\
\text { Restrictions on forest access and/or conversion }\end{array}$ & Examples of interventions in sample \\
& $\begin{array}{l}\text { Brazil: Monitoring of deforestation and forest fires by national and state } \\
\text { environmental agencies through helicopter flyovers, patrols, and fines. } \\
\text { Cameroon: Restrictions on local forest clearing and bush burning; conservation } \\
\text { and monitoring activities in the buffer area of a national park. }\end{array}$ \\
$\begin{array}{l}\text { Indonesia: Community participatory mapping to clarify village boundaries and } \\
\text { establish village land-use plans; community-led forest patrols. }\end{array}$ \\
$\begin{array}{l}\text { Peru: Land-use restrictions in Brazil nut concessions based on approved } \\
\text { management plans; forest monitoring and surveillance in indigenous territories }\end{array}$ \\
by REDD+ implementer, regional indigenous organization, and national park \\
service. \\
Tanzania: Restrictions on forest use through implementation of village forest \\
management plans.
\end{tabular}

Incentives

Nonconditional livelihood enhancements

Sustainable agriculture (i.e., alternatives to traditional swidden practices)

Sustainable animal production

Sustainable energy

Sustainable timber management

Sustainable nontimber forest product management

Forest restoration

Conditional livelihood enhancements Direct cash payments

Funds for sustainable production and infrastructure
Brazil: Technical assistance and mechanization of crop fields to stop use of fire in agriculture.

Vietnam: Support for cocoa and cashew production.

Brazil: Provision of technical assistance and inputs to raise chickens. Indonesia: Support for establishment of fish ponds, provision of floating net cages, and fish hatchlings.

Tanzania: Provision of alternative sources of energy, such as solar panels and construction of improved cook stoves.

Peru: Promotion of sustainable forest management through capacity building, construction of a timber processing plant, and reforestation with economically important timber species.

Peru: Support for production, certification, and commercialization of Brazil nuts.

Brazil: Restoration of degraded lands with agroforestry systems through provision of seedlings and technical assistance.

Indonesia: Training and piloting community-based peatland rehabilitation, which includes establishing community groups to commercially produce seedlings for planting in rehabilitation sites.

Brazil: Small bonus payment for smallholder farmers engaged in more sustainable agriculture.

Cameroon: Small bonus payment for REDD+ project participants that report illegal forest activity.

Tanzania: Trial payments for REDD+ project participants based on reduced deforestation.

Indonesia: Funding of activities related to rubber cultivation and chicken raising if villages comply with annual goals of deforestation reduction agreed upon with REDD+ project implementer.

Cameroon: Payments to local forest management committees to fund village infrastructure and microprojects, based on meeting sustainable land-use targets agreed upon with REDD+ project implementer. which were not performed by the REDD+ implementing organization but considered an integral part of the initiative strategy. At a second site in Peru, the REDD+ implementer, regional indigenous federation, and national park service were assisting with various forest monitoring and surveillance interventions in indigenous communities toward controlling illegal logging. In Cameroon, as part of one REDD+ project, there were restrictions on villagers' forest clearing and bush burning activities. At another, villagers' land use in the buffer area of a newly created national part was monitored as part of the REDD+ initiative. In Tanzania, restrictions on villagers through the implementation of forest management and land-use plans, or the creation of village groups to conserve and restore "ngitili" (enclosed) forests that restrict livestock grazing during the wet season, were integral to several REDD+ initiative strategies. In Indonesia, disincentives primarily consisted of community forest patrols and land-use planning that included restrictions on access to and conversion of forests.

Although disincentives were applied by a wider variety of actors (government agencies, REDD+ implementers, regional indigenous organizations), incentives were largely applied by the implementers of REDD+ initiatives and organizations directly affiliated with the initiative. The higher number of households targeted by incentives (Fig. 2) reflects the diversity of customized nonconditional and conditional livelihood enhancements applied 
in different contexts (Table 2). Nonconditional livelihood enhancements ranged from technical assistance and inputs for more sustainable forestry and agriculture practices to alternative energy sources (e.g., improved cook stoves). Conditional livelihood enhancements included direct cash payments to individuals or villages based on well-defined conservation behaviors, along with funds to support more sustainable land-use practices if villagers complied with forest conservation targets. Although nonconditional livelihood enhancements were applied across all 17 sites, conditional livelihood enhancements were applied with limited scope at only 7.

\section{Tenure security}

Results of the tenure security outcomes of different intervention types are shown in Table 3. At the global level, there was a decrease in tenure security over time for households exposed to disincentives alone, with the same trend observed in Brazil and Peru. In Indonesia and Tanzania, there was a clear increase in tenure security over time, which was independent of the application of any forest interventions. In Indonesia, this result could be explained by the fact that landholdings managed and used by smallholders were considered relatively secure, with village authorities increasingly playing a strong role in negotiating any conflicting land claims with both internal and external claimants (Sunderlin, de Sassi, Sills, et al., unpublished manuscript). In Tanzania, strong customary rights to community forests, which have grown over time, are likely the reason for very low levels of tenure insecurity (Sunderlin, de Sassi, Sills, et al., unpublished manuscript). Conversely, at the Vietnam site, tenure insecurity increased over time, independent of the limited application of interventions there. This result may have been associated with delays in the government's forestland allocation program for issuing smallholder land certificates, which was beyond the scope of the REDD+ initiative.

Additionally, there was participant distribution bias; people targeted for both incentives and disincentives reported higher tenure insecurity in phase 1 , but the trajectory of change over time was no different than that of the other groups (i.e., no significant change). This bias was seen in Brazil and Indonesia, with tenure insecurity decreasing over time in households that were exposed to both incentives and disincentives (although not significantly). In Brazil, the bias could be explained by the fact that several REDD+ implementers targeted areas of high additionality (i.e., high forest cover under heavy threat) that also often corresponded to areas of low tenure security (Duchelle et al. 2014; Sunderlin, de Sassi, Sills, et al., unpublished manuscript).

\section{Local knowledge of and participation in REDD+ initiatives}

In phase 2 , nearly $80 \%$ of households at REDD+ sites were aware of the local REDD+ initiative. However, household participation in initiatives was much lower. Less than $50 \%$ of households participated in any aspect of initiative design or implementation. Participation generally meant attending meetings about the local REDD+ initiative, but not participating actively in decisions related to what and how interventions would be applied.

Results of the knowledge and participation outcomes of different intervention types are shown in Table 4. At the global level, and in each country with the exception of Brazil, the group that received no interventions in phase 2 had the lowest level of
Table 3. Average percent of household total landholding (ha) considered insecure by the household in both phase 1 and phase 2.

\begin{tabular}{|c|c|c|c|c|c|}
\hline \multirow[t]{2}{*}{ Country } & \multirow{2}{*}{$\begin{array}{l}\text { Intervention } \\
\text { type }\end{array}$} & \multicolumn{2}{|r|}{ Phase 1} & \multicolumn{2}{|r|}{ Phase 2} \\
\hline & & $\mathrm{N}$ & $\begin{array}{c}\text { mean \% } \\
\text { insecure (SD) }\end{array}$ & $\mathrm{N}$ & $\begin{array}{c}\text { mean \% } \\
\text { insecure (SD) }\end{array}$ \\
\hline \multirow[t]{5}{*}{ Global } & all & 3219 & $0.17(0.36)$ & 3654 & $0.17(0.37)$ \\
\hline & none & 1472 & $0.13(0.32)$ & 1647 & $0.11(0.3)$ \\
\hline & incentives & 726 & $0.17(0.36)$ & 796 & $0.13(0.32)$ \\
\hline & disincentives & 546 & $0.21(0.4)$ & 685 & $0.32(0.46)^{*}$ \\
\hline & both & 475 & $0.23(0.42)^{*}$ & 526 & $0.22(0.41)$ \\
\hline \multicolumn{6}{|l|}{ Brazil } \\
\hline & all & 845 & $0.24(0.42)$ & 1022 & $0.28(0.45)$ \\
\hline & none & 153 & $0.25(0.43)$ & 193 & $0.28(0.45)$ \\
\hline & incentives & 220 & $0.3(0.45)$ & 231 & $0.23(0.42)$ \\
\hline & disincentives & 305 & $0.18(0.38)$ & 412 & $0.3(0.46)^{*}$ \\
\hline & both & 167 & $0.32(0.47)^{*}$ & 186 & $0.26(0.44)$ \\
\hline \multicolumn{6}{|l|}{ Peru } \\
\hline & all & 420 & $0.21(0.40)$ & 492 & $0.29(0.44)$ \\
\hline & none & 89 & $0.04(0.19)$ & 103 & $0.03(0.16)$ \\
\hline & incentives & 76 & $0(0)$ & 89 & $0.02(0.12)$ \\
\hline & disincentives & 144 & $0.36(0.46)$ & 172 & $0.5(0.48)^{*}$ \\
\hline & both & 111 & $0.32(0.46)$ & 128 & $0.43(0.48)$ \\
\hline \multicolumn{6}{|c|}{ Cameroon } \\
\hline & all & 406 & $0.07(0.25)$ & 448 & $0.08(0.25)$ \\
\hline & none & 109 & $0.09(0.26)$ & 121 & $0.1(0.28)$ \\
\hline & incentives & 138 & $0.09(0.26)$ & 152 & $0.11(0.3)$ \\
\hline & disincentives & 56 & $0.05(0.22)$ & 59 & $0.07(0.23)$ \\
\hline & both & 103 & $0.06(0.23)$ & 116 & $0.02(0.13)$ \\
\hline \multicolumn{6}{|c|}{ Tanzania } \\
\hline & all & 343 & $0.06(0.23)$ & 370 & $0.0(0.05)^{*}$ \\
\hline & none & 221 & $0.08(0.27)$ & 244 & $0(0.06)$ \\
\hline & incentives & 49 & $0.02(0.14)$ & 52 & $0(0)$ \\
\hline & disincentives & 20 & $0.03(0.12)$ & 21 & $0(0)$ \\
\hline & both & 53 & $0(0)$ & 53 & $0(0)$ \\
\hline \multicolumn{6}{|c|}{ Indonesia } \\
\hline & all & 989 & $0.17(0.36)$ & 1107 & $0.11(0.29)^{*}$ \\
\hline & none & 726 & $0.15(0.33)$ & 813 & $0.1(0.28)$ \\
\hline & incentives & 201 & $0.18(0.38)$ & 230 & $0.1(0.28)$ \\
\hline & disincentives & 21 & $0.17(0.36)$ & 21 & $0.13(0.28)$ \\
\hline & both & 41 & $0.38(0.48)^{*}$ & 43 & $0.26(0.41)$ \\
\hline \multicolumn{6}{|l|}{ Vietnam } \\
\hline & all & 216 & $0.12(0.26)$ & 215 & $0.20(0.38)^{*}$ \\
\hline & none & 174 & $0.11(0.24)$ & 173 & $0.21(0.39)$ \\
\hline & incentives & 42 & $0.15(0.32)$ & 42 & $0.17(0.33)$ \\
\hline
\end{tabular}

*Significant difference in the regression models at $p<0.05$. In the phase 1 column, this symbol shows a significant difference at baseline relative to the group that received no interventions, i.e., a selection effect. In the phase 2 column, this symbol shows a significant difference in the group (table line) over time.

awareness of and involvement in the local REDD+ initiative. In Brazil, households subjected to disincentives were the least aware of the REDD+ initiative and also participated the least. Importantly, the main disincentives applied at the Brazilian sites were national-level regulatory measures (e.g., environmental fines) that fell outside the purview of REDD+ implementers. Households at REDD+ sites could easily be subjected to these disincentives, which had been broadly applied across the Brazilian Amazon, without having participated directly in the local REDD+ initiative. Conversely, in Peru, households that 
Table 4. Percent of households at REDD+ sites in phase 2 reporting knowledge of and participation in local REDD+ initiatives, expressed as \% of "yes" answers (standard deviation).

\begin{tabular}{|c|c|c|c|c|c|c|c|}
\hline \multirow[b]{2}{*}{ Country } & \multirow[b]{2}{*}{ Intervention type } & \multicolumn{3}{|c|}{ Knowledge } & \multicolumn{3}{|c|}{ Participation } \\
\hline & & $\mathrm{N}$ & Yes $\%(\mathrm{SD})$ & Rank $^{\dagger}$ & $\mathrm{N}$ & Yes $\%(\mathrm{SD})$ & $\operatorname{Rank}^{\dagger}$ \\
\hline \multirow[t]{4}{*}{ Global } & none & 769 & $55.5(49.7)$ & 3 & 427 & $24.36(43.0)$ & 3 \\
\hline & incentives & 602 & $89.9(30.2)$ & 1 & 541 & $57.86(49.4)$ & 2 \\
\hline & disincentives & 318 & $80.8(39.4)$ & 2 & 257 & $33.46(47.3)$ & 2 \\
\hline & both & 429 & $94.9(22.1)$ & 1 & 407 & $73.96(43.9)$ & 1 \\
\hline \multicolumn{8}{|l|}{ Brazil } \\
\hline & none & 117 & $81.2(39.2)$ & 2 & 95 & $7.37(26.3)$ & 3 \\
\hline & incentives & 126 & $97.6(15.3)$ & 1 & 123 & $61.79(48.8)$ & 1 \\
\hline & disincentives & 209 & $73.2(44.3)$ & 3 & 153 & $13.73(34.5)$ & 2 \\
\hline & both & 153 & $89.5(30.7)$ & 1 & 137 & $57.66(49.5)$ & 1 \\
\hline \multicolumn{8}{|l|}{ Peru } \\
\hline & none & 54 & $68.5(46.8)$ & 3 & 37 & $62.16(49.1)$ & 1 \\
\hline & incentives & 51 & $86.3(34.7)$ & 3 & 44 & $63.64(48.7)$ & 1 \\
\hline & disincentives & 77 & $97.4(16.1)$ & 1 & 75 & $57.33(49.8)$ & 1 \\
\hline & both & 67 & $92.5(26.4)$ & 2 & 62 & $75.81(43.1)$ & 1 \\
\hline \multicolumn{8}{|c|}{ Cameroon } \\
\hline & none & 24 & $70.8(46.4)$ & 2 & 17 & $64.71(49.2)$ & 2 \\
\hline & incentives & 110 & $95.5(20.9)$ & 1 & 105 & $50.48(50.2)$ & 2 \\
\hline & disincentives & 7 & $100.0(0)$ & 1 & 7 & $85.71(37.7)$ & $\mathrm{x}$ \\
\hline & both & 113 & $100.0(0)$ & 1 & 113 & $82.30(38.3)$ & 1 \\
\hline \multicolumn{8}{|l|}{ Tanzania } \\
\hline & none & 96 & $64.6(48.0)$ & 2 & 62 & $33.87(47.7)$ & 2 \\
\hline & incentives & 56 & $100.0(0)$ & 1 & 56 & $73.21(44.7)$ & 1 \\
\hline & disincentives & 1 & $100.0(0)$ & 1 & 1 & $100.00(0)$ & $\mathrm{x}$ \\
\hline & both & 53 & $100.0(0)$ & 1 & 53 & $100.00(0)$ & 1 \\
\hline \multicolumn{8}{|l|}{ Indonesia } \\
\hline & none & 383 & $50.7(50.1)$ & 2 & 194 & $20.62(40.6)$ & 2 \\
\hline & incentives & 231 & $86.6(34.1)$ & 1 & 200 & $56.00(49.7)$ & 1 \\
\hline & disincentives & 24 & $87.5(33.8)$ & 1 & 21 & $71.43(46.3)$ & 1 \\
\hline & both & 43 & $97.7(15.2)$ & 1 & 42 & $69.05(46.8)$ & 1 \\
\hline \multicolumn{8}{|l|}{ Vietnam } \\
\hline & none & 95 & $23.2(42.4)$ & 2 & 22 & $9.09(29.4)$ & 1 \\
\hline & incentives & 28 & $46.4(50.8)$ & 1 & 13 & $23.08(43.8)$ & 1 \\
\hline
\end{tabular}

${ }^{\dagger}$ Rank shows the statistical difference between pairwise intervention types. Rank constitutes significant differences $(\mathrm{p}<0.05)$ with 1 depicting the highest and 3 the lowest percentage of households aware of and participating in local REDD+ initiatives. Rank marked with an " $\mathrm{x}$ " indicates an insufficient sample size to obtain meaningful results.

experienced disincentives had the highest awareness of the initiative, meaning that this type of intervention was central to the local REDD+ strategy. For instance, at one site in the Peruvian Amazon, the REDD+ implementing organization involved community members in forest monitoring activities designed to curb illegal logging. At sites in Indonesia, Cameroon, and Tanzania, households exposed to (almost) any type of intervention were generally well aware of the local REDD+ initiative but had participated less in its design and implementation. At the Vietnam site, given the premature ending of the initiative, we observed low levels of knowledge and participation overall. However there were still higher percentages for those targeted by interventions (in this case, incentives only) when compared with those who were not involved.

\section{Well-being}

Results of the overall well-being outcomes are shown in Table 5 with country level results in Appendix 1. At the global level, we found a positive correlation with well-being for all intervention types (incentives, disincentives, both) at baseline, indicating that participating households were generally on a more positive trajectory of well-being than nonparticipating households. In phase 2, however, among households subject to disincentives, there was a decrease in the number of households reporting to be better off, along with an increase in the number reporting to be worse off. However, there was no change in the households receiving both disincentives and incentives, meaning that the general worsening of well-being due to disincentives was alleviated by the addition of incentives. At the country level (Appendix 1, Table A1.1), other patterns were detected. At sites in Indonesia, households targeted by incentives were worse off at baseline, and their perceptions of well-being improved significantly from phase 1 to phase 2 . In Peru, those targeted for disincentives (both with incentives and alone) were at two ends of the well-being spectrum: those who were the best off or the worst off in phase 1 with no significant changes over time in either group. Finally, in Tanzania, households targeted for disincentives reported being less worse off over time. This result could be explained by activities in this intervention category that restricted access to forests by external claimants, thus strengthening local land rights and increasing subjective well-being. 
Table 5. Changes in overall subjective well-being over time

\begin{tabular}{|c|c|c|c|c|c|c|c|c|c|}
\hline \multirow{3}{*}{ Country } & \multirow{3}{*}{$\begin{array}{l}\text { Intervention } \\
\text { type }\end{array}$} & \multicolumn{4}{|c|}{ A) Better off (yes/no) } & \multicolumn{4}{|c|}{ B) Worse off (yes/no) } \\
\hline & & \multicolumn{2}{|c|}{ Phase 1} & \multicolumn{2}{|c|}{ Phase 2} & \multicolumn{2}{|c|}{ Phase 1} & \multicolumn{2}{|c|}{ Phase 2} \\
\hline & & $\mathrm{N}$ & mean (SD) & $\mathrm{N}$ & mean (SD) & $\mathrm{N}$ & mean (SD) & $\mathrm{N}$ & mean (SD) \\
\hline \multirow[t]{4}{*}{ Global } & none & 1706 & $0.32(0.46)$ & 1901 & $0.34(0.47)$ & 1706 & $0.28(0.45)$ & 1901 & $0.27(0.44)$ \\
\hline & incentives & 774 & $0.43(0.5)^{*}$ & 841 & $0.43(0.49)$ & 774 & $0.28(0.45)$ & 841 & $0.24(0.43)$ \\
\hline & disincentives & 553 & $0.52(0.5)^{*}$ & 697 & $0.47(0.5)^{*}$ & 553 & $0.2(0.4)^{*}$ & 697 & $0.23(0.42)^{*}$ \\
\hline & both & 478 & $0.48(0.5)^{*}$ & 529 & $0.48(0.5)$ & 478 & $0.23(0.42)^{*}$ & 529 & $0.23(0.42)$ \\
\hline
\end{tabular}

*Significant differences in the regression models at $\mathrm{p}<0.05$. In the phase 1 column, this symbol indicates a significant difference in the first phase of the research (i.e. baseline) relative to the control group. In the phase 2 column, this symbol shows a significant difference within the group (table line) over time.

Results of perceived effects of specific types of interventions on household well-being provide further insights (Table 6). At the global level, incentives were considered to have had the most positive effect on well-being (i.e., higher Likert scores) followed by a combination of disincentives and incentives, and disincentives alone, with highly significant differences among all groups. These results were mirrored in Brazil with the same sequence and high significance. In contrast, in Peru there was no difference between disincentives alone and in combination with incentives in terms of positive well-being scores, meaning that specific disincentives were not necessarily considered negative. This interpretation could also apply to findings from Indonesia. Although in the previous analysis, there was an increase in general well-being associated with incentives in Indonesia, this analysis showed no difference between intervention types. These results are not necessarily at odds, but simply demonstrate that the general assessment of specific disincentives was just as positive as the assessment of incentives; again suggesting disincentives pose a relatively minor burden to smallholders and possibly some benefits. In Tanzania, disincentives alone were considered significantly more positive than the two other categories. Again, this is likely because of the nature of those restrictions, which were implemented by villagers and might be considered a way to help exclude external claimants from locally important forests. In Cameroon, incentives were viewed significantly more positively than the other two categories. Vietnam was not included in this analysis as no disincentives were applied there.

\section{Reported forest clearing}

Results of the forest clearing outcomes of different intervention packages are shown in Figure 3. At the global level, the distribution of disincentives was skewed toward households with higher reported forest clearing at baseline. Furthermore, these households reported clearing significantly less forest in phase 2 than households receiving other types of interventions (or no interventions at all). At the country level, these patterns held true in Brazil and Peru, but with a significant reduction in forest clearing among households with higher forest clearing at baseline observed in Brazil only. In all other countries, the distribution of disincentives was not correlated with households' forest clearing at baseline. The significant reduction in reported forest clearing in Cameroon and Tanzania was independent of intervention type. In Indonesia, the increase in forest clearing for households experiencing disincentives was not statistically significant at the country level, although Figure 3 suggests that it may be the case in a particular village or site with higher-than-average clearing.
Table 6. Household-level average (and standard deviation) of well-being scores for the different intervention types.

\begin{tabular}{llccc}
\hline \hline Country & $\begin{array}{l}\text { Intervention } \\
\text { type }\end{array}$ & $\mathrm{N}$ & $\begin{array}{c}\text { Mean bundle } \\
\text { score (SD) }\end{array}$ & Rank $^{\dagger}$ \\
\hline Global & incentives & 799 & $3.64(0.25)$ & 1 \\
& disincentives & 699 & $3.37(0.2)$ & 3 \\
Brazil & both & 529 & $3.54(0.17)$ & 2 \\
& incentives & 236 & $3.52(0.3)$ & 1 \\
& disincentives & 419 & $2.94(0.06)$ & 3 \\
Cameroon & both & 188 & $3.18(0.24)$ & 2 \\
& incentives & 164 & $3.79(0.42)$ & 1 \\
& disincentives & 61 & $2.99(0.36)$ & 2 \\
Indonesia & both & 117 & $3.56(0.19)$ & 2 \\
& incentives & 253 & $3.54(0.21)$ & 1 \\
& disincentives & 24 & $3.57(0.36)$ & 1 \\
& both & 43 & $3.56(0.15)$ & 1 \\
Peru & incentives & 90 & $3.13(0.19)$ & 2 \\
& disincentives & 173 & $3.37(0.16)$ & 1 \\
& both & 128 & $3.32(0.16)$ & 1 \\
Tanzania & incentives & 56 & $3.9(0.14)$ & 2 \\
& disincentives & 22 & $4.2(0.05)$ & 1 \\
& both & 53 & $4.04(0.09)$ & 2 \\
\hline
\end{tabular}

Rank constitutes significant differences $(\mathrm{p}<0.05)$ between groups, with 1 depicting the highest and 3 the lowest well-being score associated with different intervention types. Thus, in each country, groups with equivalent ranks are not significantly different from each other, whereas groups with different ranks are significantly different.

\section{DISCUSSION}

\section{Balancing intervention strategies to ensure social safeguards in} REDD+ implementation

Our results highlight how the varieties of incentives and disincentives, which are being implemented across the tropics to protect and enhance forests, have clear implications for local people. Brazil's recent success in reducing Amazonian deforestation has been attributed to disincentives (i.e., heavy command-and-control measures; Assunção et al. 2012), and there are calls for a more balanced mix of policy instruments that include incentives for landholders to conserve forests (Nepstad et 
Fig. 3. Difference in reported forest clearing from phase 1 to phase 2 by households targeted by different intervention types.

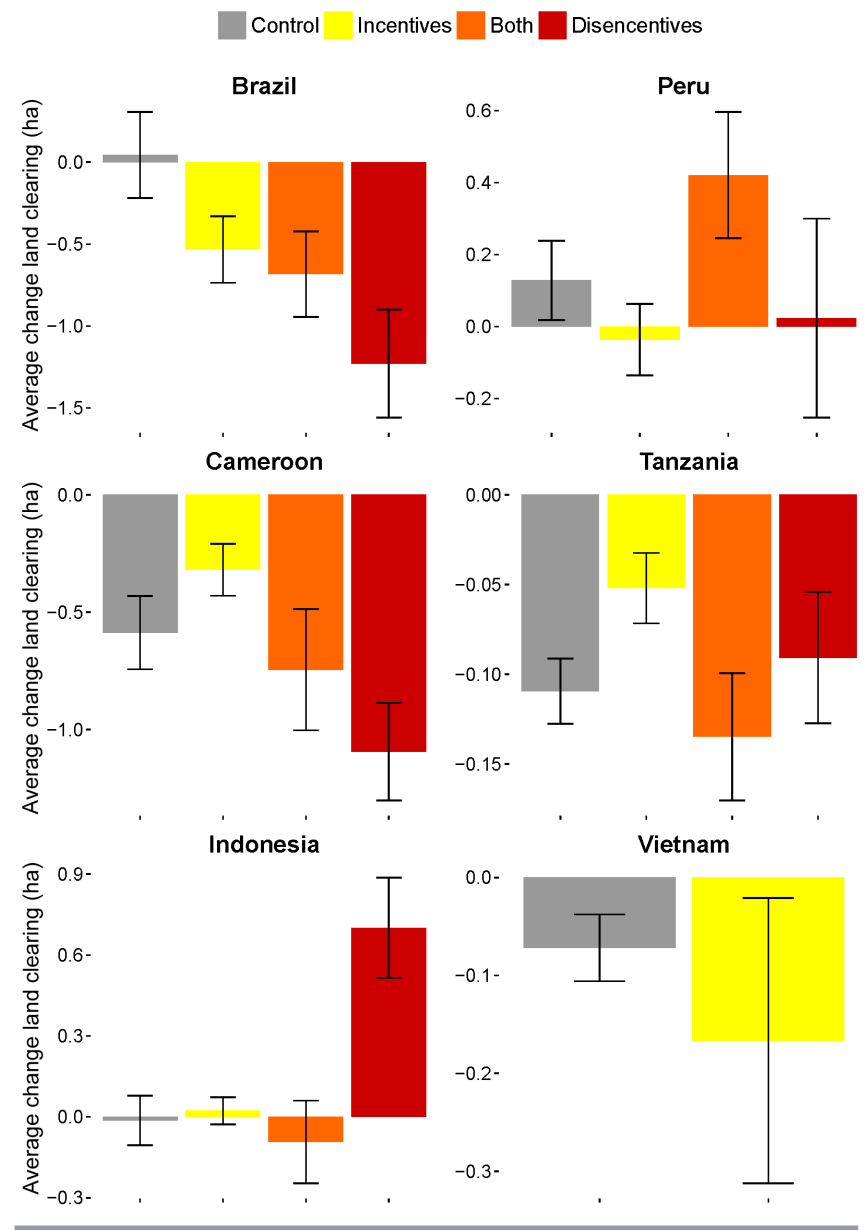

al. 2014). There is evidence from the Brazilian Amazon that such policy mixes could be cost-effective and probably socially desirable, if designed in a balanced way. Introducing payments for environmental services (PES) as a complement to commandand-control measures could help balance the costs and benefits of conservation for local landholders (Börner et al. 2015). This is consistent with findings from a protected area in Rwanda highlighting how PES introduced new motivations, which were linked to perceptions of equity, for local farmers to conserve forest (Martin et al. 2014). Implementers of early REDD+ initiatives are experimenting with such intervention mixes, and there are important lessons to be learned from the local impacts of the different strategies.

Our analysis focused on the effect of different types of interventions on tenure security, local awareness of and participation in REDD+, and subjective well-being, which are all key elements of REDD+ social safeguards. We found that disincentives more than incentives were driving the observed patterns. There was a clear correlation between exposure to disincentives and a general decrease in perceived well-being across the global sample. Disincentives alone were associated with decreased tenure security in Brazil and Peru, which could be because there was greater effort in applying disincentives than incentives in those two countries. Moreover, the net effect of one powerful disincentive, such as an expensive fine, may affect local people more than a set of smaller incentives. Indeed, as seen from households' evaluation of specific interventions on their wellbeing, there was a clear negative effect on subjective well-being of strictly enforced regulatory measures in Brazil. However, when disincentives were combined with incentives, negative effects on household well-being were alleviated, highlighting the importance of incentives in the intervention mix. In Indonesia, where more households were exposed to incentives, there was a clear increase in general well-being associated with households that had received the intervention. Interestingly, there may also be an upside to disincentives. In Indonesia and Tanzania, specific regulatory measures either did not affect smallholders negatively or they possibly provided some benefits (i.e., helping to defend lands against unwanted external users). This result makes sense in that REDD+ implementers in Tanzania engaged local people in applying restrictions, and several communities in Indonesia were involved in monitoring local landholdings. These regulatory measures were very different from the top-down command-andcontrol measures observed in Brazil.

\section{Trade-offs between carbon and noncarbon benefits, and who decides?}

There is a trade-off between the carbon effectiveness of disincentives and their perceived effects on tenure security and well-being. Our research supports other empirical findings on the effectiveness of command-and-control measures in curbing forest clearing in Brazil (Assunção et al. 2012). In this case, it is as they relate to smallholder farmers. In Brazil, where disincentives were correlated with fewer hectares of forest cleared, they were also correlated with decreased tenure security and negative effects on household well-being. In Peru, disincentives had no bearing on forest clearing, and concurrently there was no change in household well-being, but were correlated with a decrease in tenure security, possibly due to increased surveillance of local landholdings. At sites in Indonesia and Tanzania, where disincentives did not affect forest clearing by smallholders, they were viewed more favorably. Because most households in our global sample are highly dependent on agricultural income, and by extension forest clearing, for their livelihoods (de Sassi et al. 2014), such trade-offs need to be addressed.

There is an inherent tension between carbon and noncarbon values in REDD+. Because the primary goal of the mechanism is to reduce deforestation and forest degradation, the UNFCCC strengthened noncarbon values through linking REDD+ safeguard information systems to results-based finance (UNFCCC 2014). Although social safeguards have the potential to empower local people in REDD+, the clear rules and guidance that are in place for measurement, reporting, and verification of carbon emissions do not exist for assessing the social performance of REDD+ (Duchelle et al. 2015). Thus, REDD+ is still open to interpretation by different actors with different interests on acceptable level of trade-offs between carbon and noncarbon goals (McDermott et al. 2012).

Such disconnects are apparent between REDD+ implementers and local people (Ravikumar et al. 2015). Implementers of the 
REDD+ initiatives in our study largely focused on small-scale agriculture as a driver of deforestation (Sunderlin et al. 2015), thus supporting restrictions on clearing and burning forests and providing incentives to smallholders for more sustainable agricultural practices. However, monetary incentives to curb traditional swidden practices were often too small to adequately compensate farmers for the loss of agricultural income, and technical assistance was lacking to help them engage in new production techniques. At a REDD+ project site in Madagascar in which rural people were compensated for forest use restrictions imposed by a national park, there was evidence of elite capture as social safeguard assessors were more likely to compensate households with greater social-political power and higher food security due to their inability to understand the local context (Poudyal et al. 2016). At a REDD+ project site in Mexico, the local community's worldview of sustainability through entrepreneurial forest use contrasted remarkably with the project implementer's focus on strict conservation, highlighting the limited ability of safeguards to benefit local people when decisions about interventions are made without adequate local engagement (McDermott and Ituarte-Lima 2016).

Full and effective participation, as articulated in REDD+ safeguard (d), is one key element of such engagement. Most implementers of the REDD+ initiatives in our sample had engaged in or planned to engage in the free prior informed consent (FPIC) process with local stakeholders (Jagger et al. 2014), and a range of benefit sharing mechanisms were being tested at these sites (Luttrell et al. 2013). That said, getting the balance of incentives and disincentives right is key to minimizing social risks (do no harm) and promoting social cobenefits (do good). Our findings highlight that in Indonesia, Cameroon, and Tanzania, there were relatively high levels of awareness of the local REDD+ initiatives among participants subjected to most intervention types. However, in general, smallholders did not really have a say in what types of interventions should be implemented in their communities. Because FPIC is an important entry point to guaranteeing local rights, broader engagement is needed for designing interventions that can benefit both local people and forests (Cromberg et al. 2014).

\section{CONCLUSION}

Despite broad interest in minimizing risks and maximizing benefits for local people in REDD+, there has been minimal empirical evaluation of the social impacts of REDD+ or operationalization of social safeguards. This research addresses that gap through analyzing the effects of different types of forest interventions on key social safeguard indicators. Because the interventions examined go beyond those solely applied by REDD+ implementers, our findings highlight the importance of ensuring that interventions designed to protect forests also benefit local people. Although extra effort is needed to adequately measure social impacts at the local level, there are clearly good reasons to do so. Disincentives can have negative impacts on smallholders' rights and well-being, and possibly even more so when they effectively decrease forest clearing, inhibiting local livelihoods. Incentives can help alleviate the burden of disincentives, but the right balance is needed. Local perceptions of the social impacts of forest interventions must be prioritized in safeguards monitoring because individual farmers and communities across the tropics will ultimately make the collective difference in how forests are managed. The principles outlined in the UNFCCC REDD+ safeguards are at the heart of the sustainable development goals, and there are clear synergies between the urgent climate and sustainable development agendas. Social monitoring based on robust impact evaluation methods and grounded in local perspectives and processes, can help harness these synergies and provide the needed evidence for sound environmental and social policymaking in tropical forest countries.

Responses to this article can be read online at: http://www.ecologyandsociety.org/issues/responses. php/9334

\section{Acknowledgments:}

We thank the members of our field teams for their contribution in carrying out this research, our in-country partners for their collaboration, and the men and women of participating communities for sharing their time and insights. The funding partners that supported this research include the Norwegian Agency for Development Cooperation (Norad), the Australian Department of Foreign Affairs and Trade (DFAT), the European Union (EU), the International Climate Initiative (IKI) of the German Federal Ministry for the Environment, Nature Conservation, Building and Nuclear Safety (BMUB), the Department for International Development (UKAID), and the CGIAR Research Program on Forests, Trees and Agroforestry (CRP-FTA), with financial support from the donors contributing to the CGIAR Fund. This article benefited from the valuable inputs of Abdon Awono, Thu Ba Huynh, Mella Komalasari, Demetrius Kweka, Lauren Masatsugu, and Gabriela Simonet, along with those of two anonymous reviewers and the journal subject editor.

\section{LITERATURE CITED}

Agrawal, A., D. Nepstad, and A. Chhatre. 2011. Reducing emissions from deforestation and forest degradation. Annual Review of Environmental Resources 36:373-396. http://dx.doi. org/10.1146/annurev-environ-042009-094508

Assunção, J., C. C. e Gandour, and R. Rocha. 2012. Deforestation slowdown in the Legal Amazon: prices or policies? Climate Policy Initiative, Pontifical Catholic University, Rio de Janeiro, Brazil. [online] URL: http://climatepolicyinitiative.org/wp-content/ uploads/2012/03/Deforestation-Prices-or-Policies-Working-Paper. pdf

Bates, D., M. Mächler, B. Bolker, and S. Walker. 2015. Fitting linear mixed-effects models using lme4. Journal of Statistical Software 67(1):1-48. http://dx.doi.org/10.18637/jss.v067.i01

Börner, J., E. Marinho, and S. Wunder. 2015. Mixing carrots and sticks to conserve forests in the Brazilian Amazon: a spatial probabilistic modeling approach. PLoS ONE 10(2):e0116846. http://dx.doi.org/10.1371/journal.pone.0116846

Caplow, S., P. Jagger, K. Lawlor, and E. Sills. 2011. Evaluating land use and livelihood impacts of early forest carbon projects: lessons for learning about REDD+. Environmental Science and Policy 14:152-167. http://dx.doi.org/10.1016/j.envsci.2010.10.003 
Chhatre, A., S. Lakhanpal, A. M. Larson, F. Nelson, H. Ojha, and J. Rao. 2012. Social safeguards and co-benefits in REDD+: a review of the adjacent possible. Current Opinion in Environmental Sustainability 4:654-660. http://dx.doi.org/10.1016/ j.cosust.2012.08.006

Corbera, E., M. Estrada, P. May, G. Navarro, and P. Pacheco. 2011. Rights to land, forests and carbon in REDD+: insights from Mexico, Brazil and Costa Rica. Forests 2:301-342. http://dx.doi. org/10.3390/f2010301

Cromberg, M., A. E. Duchelle, and I. O. Rocha. 2014. Local participation in REDD+: lessons from the eastern Brazilian Amazon. Forests 5(4):579-598. http://dx.doi.org/10.3390/f5040579

de Sassi, C., W. D. Sunderlin, E. O. Sills, A. E. Duchelle, A. Ravikumar, I. A. P. Resosudarmo, C. Luttrell, S. Joseph, M. Herold, D. L. Kweka, and S. S. Atmadja. 2014. REDD+ on the ground: global insights from local contexts. Pages 420-439 in E. O. Sills, S. S. Atmadja, C. de Sassi, A. E. Duchelle, D. L. Kweka, I. A. P. Resosudarmo, and W. Sunderlin, editors. REDD+ on the ground: a case book of subnational initiatives across the globe. CIFOR, Bogor, Indonesia. [online] URL: http://www.cifor.org/ library/5202/redd-on-the-ground-a-case-book-of-subnational-initiativesacross-the-globel

Duchelle, A. E., M. Cromberg, M. F. Gebara, R. Guerra, T. Melo, A. Larson, P. Cronkleton, J. Börner, E. Sills, S. Wunder, S. Bauch, P. May, G. Selaya, and W. D. Sunderlin. 2014. Linking forest tenure reform, environmental compliance, and incentives: lessons from REDD+ initiatives in the Brazilian Amazon. World Development 55:53-67. http://dx.doi.org/10.1016/j.worlddev.2013.01.014

Duchelle, A. E., M. Herold, and C. de Sassi. 2015. Monitoring REDD+ impacts: cross scale coordination and interdisciplinary integration. Pages 55-79 in A. Latawiec and D. Agol, editors. Sustainability indicators in practice. De Gruyter/Harvard University Press, Warsaw, Poland/Berlin, Germany. http://dx.doi. org/10.1515/9783110450507-009

Harrison, X. A. 2014. Using observation-level random effects to model overdispersion in count data in ecology and evolution. PeerJ 2:e616.

Hothorn, T., F. Bretz, and P. Westfall. 2008. Simultaneous inference in general parametric models. Biometrical Journal 50 (3):346-363. http://dx.doi.org/10.1002/bimj.200810425

Huynh, T. B. 2014. Cat Loc landscape - Cat Tien National Park pro-poor REDD+ Project, Vietnam. Pages 401-417 in E. O. Sills, S. S. Atmadja, C. de Sassi, A. E. Duchelle, D. L. Kweka, I. A. P. Resosudarmo, and W. Sunderlin, editors. REDD+ on the ground: a case book of subnational initiatives across the globe. CIFOR, Bogor, Indonesia. [online] URL: http://www.cifor.org/library/5202/ redd-on-the-ground-a-case-book-of-subnational-initiatives-acrossthe-globel

Intergovernmental Panel on Climate Change (IPCC). 2014. Agriculture, forestry and other land use (AFOLU). Pages 811-922 in O. Edenhofer, R. Pichs-Madruga, Y. Sokona, E. Farahani, S. Kadner, K. Seyboth, A. Adler, I. Baum, S. Brunner, P. Eickemeier, et al., editors. Climate change 2014: mitigation of climate change. Contribution of Working Group III to the Fifth Assessment Report of the Intergovernmental Panel on Climate Change.
Chapter 11. Cambridge University Press, Cambridge, UK. [online] URL: http://www.ipcc.ch/report/ar5/wg3/

Jagger, P., M. Brockhaus, A. E. Duchelle, M. F. Gebara, K. Lawlor, I. A. P. Resosudarmo, and W. D. Sunderlin. 2014. Multilevel policy dialogues, processes, and actions: challenges and opportunities for national REDD+ safeguards measurement, reporting, and verification (MRV). Forests 5(9):2136-2162. http:// dx.doi.org/10.3390/f5092136

Jagger, P., and P. Rana. 2017. Using publicly available social and spatial data to evaluate progress on REDD+ social safeguards in Indonesia. Environmental Science and Policy 76:59-69. http://dx. doi.org/10.1016/j.envsci.2017.06.006

Larson, A. M., M. Brockhaus, W. D. Sunderlin, A. E. Duchelle, A. Babon, T. Dokken, T. T. Pham, I. A. P. Resosudarmo, G. Selaya, A. Awono., and T.-B. Huynh. 2013. Land tenure and REDD+: the good, the bad and the ugly. Global Environmental Change 23(3):678-689. http://dx.doi.org/10.1016/j.gloenvcha.2013.02.014

Lawlor, K. 2013. Methods for assessing and evaluating social impacts of program-level REDD+. United States Agency for International Development, Forest Carbon, Markets and Communities (FCMC) Program, Arlington, Virginia, USA. [online] URL: http://www.fomcglobal.org/documents/

LISA REDD Methods Review.pdf

Le Quéré, C., R. Moriarty, R. M. Andrew, J. G. Canadell, S. Sitch, J. I. Korsbakken, P. Friedlingstein, G. P. Peters, R. J. Andres, T. A. Boden, R. A. Houghton, J. I. House, R. F. Keeling, P. Tans, P. Ciais, A. Arneth, D. C. E. Bakker, L. Barbero, L. Bopp, J. Chang, F. Chevallier, L. P. Chini, P. Ciais, M. Fader, R. A. Feely, T. Gkritzalis, I. Harris, J. Hauck, T. Ilyina, A. K. Jain, E. Kato, V. Kitidis, K. Klein Goldewijk, C. Koven, P. Landschützer, S. K. Lauvset, N. Lefèvre, A. Lenton, I. D. Lima, N. Metzl, F. Millero, D. R. Munro, A. Murata, J. E. M. S. Nabel, S. Nakaoka, Y. Nojiri, K. O'Brien, A. Olsen, T. Ono, F. F. Pérez, B. Pfeil, D. Pierrot, B. Poulter, G. Rehder, C. Rödenbeck, S. Saito, U. Schuster, J. Schwinger, R. Séférian, T. Steinhoff, B. D. Stocker, A. J. Sutton, T. Takahashi, B. Tilbrook, I. T. van der Laan-Luijkx, G. R. van der Werf, S. van Heuven, D. Vandemark, N. Viovy, A. Wiltshire, S. Zaehle, and N. Zeng. 2015. Global carbon budget 2015. Earth System Science Data 7:349-396. http://dx.doi.org/10.5194/ essd-7-349-2015

Luttrell, C., L. Loft, M. F. Gebara, D. Kweka, M. Brockhaus, A. Angelsen, and W. D. Sunderlin. 2013. Who should benefit from REDD+? Rationales and realities. Ecology and Society 18(4):52. http://dx.doi.org/10.5751/es-05834-180452

Martin, A., N. Gross-Camp, B. Kebede, and S. McGuire. 2014. Measuring effectiveness, efficiency and equity in an experimental payments for ecosystem services trial. Global Environmental Change 28:216-226. http://dx.doi.org/10.1016/j.gloenvcha.2014.07.003

McDermott, C. L., L. Coad, A. Helfgott, and H. Schroeder. 2012. Operationalizing social safeguards in REDD+: actors, interests and ideas. Environmental Science and Policy 21:63-72. http://dx. doi.org/10.1016/j.envsci.2012.02.007

McDermott, C. L., and C. Ituarte-Lima. 2016. Safeguarding what and for whom? The role of institutional fit in shaping REDD+ in Mexico. Ecology and Society 21(1):9. http://dx.doi.org/10.5751/ es-08088-210109 
Merriam-Webster. 2010. Merriam-Webster online dictionary. Merriam-Webster, Springfield, Massachusetts, USA. http://www. merriam-webster.com/dictionary/well-being

Nepstad, D., D. McGrath, C. Stickler, A. Alencar, A. Azevedo, B. Swette, T. Bezerra, M. DiGiano, J. Shimada, R. Seroa da Motta, E. Armijo, L. Castello, P. Brando, M. C. Hansen, M. McGrath-Horn, O. Carvalho, and L. Hess. 2014. Slowing Amazon deforestation through public policy and interventions in beef and soy supply chains. Science 344:1118-1123. http://dx.doi. org/10.1126/science. 1248525

Poudyal, M., B. S. Ramamonjisoa, N. Hockley, O. S. Rakotonarivo, J. M. Gibbons, R. Mandimbiniaina, A. Rasoamanana, and J. P. G. Jones. 2016. Can REDD+ social safeguards reach the 'ight' people? Lessons from Madagascar. Global Environmental Change 37:31-42. http://dx.doi.org/10.1016/ j.gloenvcha.2016.01.004

R Core Team. 2015. R: a language and environment for statistical computing. R Foundation for Statistical Computing, Vienna, Austria. [online] URL: https://www.R-project.org

Ravikumar, A., A. M. Larson, A. E. Duchelle, R. Myers, and J. Gonzales Tovar. 2015. Multilevel governance challenges in transitioning towards a national approach for REDD+: evidence from 23 subnational REDD+ initiatives. International Journal of the Commons 9(2):909-931. http://dx.doi.org/10.18352/ijc.593

Sills, E. O., S. S. Atmadja, C. de Sassi, A. E. Duchelle, D. L. Kweka, I. A. P. Resosudarmo, and W. D. Sunderlin. 2014. REDD+ on the ground: a case book of subnational initiatives across the globe. CIFOR, Bogor, Indonesia. [online] URL: http://www.cifor.org/ library/5202/redd-on-the-ground-a-case-book-of-subnational-initiativesacross-the-globel

Simonet, G., A. Karsenty, P. Newton, C. de Perthuis, B. Schaap, and C. Seyller. 2015. REDD+ projects in 2014: an overview based on a new database and typology. Information and Debate Series 32. Paris-Dauphine University, Climate Economics Chair, Paris, France. [online] URL: http://www.chaireeconomieduclimat.org/ en/publications-en/information-debates/id-32-redd-projects-in-2014an-overview-based-on-a-new-database-and-typology/

Sunderlin, W. D., C. de Sassi, A. D. Ekaputri, M. Light, C. D. Pratama. 2017. REDD+ contribution to well-being and income is marginal: the perspective of local stakeholders. Forests. 8 (4):125. http://dx.doi.org/10.3390/f8040125

Sunderlin, W. D., A. M. Larson, A. E. Duchelle, I. A. P. Resosudarmo, T. B. Huynh, A. Awono, and T. Dokken. 2014. How are REDD+ proponents addressing tenure problems? Evidence from Brazil, Cameroon, Tanzania, Indonesia, and Vietnam. World Development 55:37-52. http://dx.doi.org/10.1016/ j.worlddev.2013.01.013

Sunderlin, W. D., A. M. Larson, A. E. Duchelle, E. O. Sills, C. Luttrell, P. Jagger, S. K. Pattanayak, P. Cronkleton, A. D. Ekaputri, C. de Sassi, R. Aryani, and G. Simonet. 2016. Technical guidelines for research on REDD+ subnational initiatives. CIFOR, Bogor, Indonesia. [online] URL: http://www.cifor.org/library/6009/ technical-guidelines-for-research-on-redd-subnational-initiatives/
Sunderlin, W. D., E. O Sills, A. E. Duchelle, A. D. Ekaputri, D. Kweka, M. A. Toniolo, S. Ball, N. Doggart, C. D. Pratama, J. T. Padilla, A. Enright, and R. M. Otsyina. 2015. REDD+ at a critical juncture: assessing the limits of polycentric governance for achieving climate change mitigation. International Forestry Review 17(4):400-413. http://dx.doi.org/10.1505/146554815817476468

United Nations Framework Convention on Climate Change (UNFCCC). 2011. The Cancun agreements: outcome of the work of the ad hoc working group on long-term cooperation under the convention. Decision 1/CP.16. Report of the conference of the parties on its sixteenth session, Cancun, 29 November-10 December 2010. FCC/CP/2010/7 Add.1. United Nations Framework Convention on Climate Change, Bonn, Germany. [online] URL: https://unfccc.int/resource/docs/2010/cop16/eng/07a01.pdf

United Nations Framework Convention on Climate Change (UNFCCC). 2014. Work programme on results-based finance to progress the full implementation of the activities referred to in decision 1/CP.16, paragraph 70. Decision 9/CP.19. Report of the conference of the parties on its nineteenth session, Warsaw, 11-23 November 2013. FCC/CP/2013/10 Add.1. United Nations Framework Convention on Climate Change, Bonn, Germany. [online] URL: http://unfccc.int/resource/docs/2013/cop19/eng/10a01. pdf

Woodhouse, E., K. M. Homewood, E. Beauchamp, T. Clements, J. T. McCabe, D. Wilkie, and E. J. Milner-Gulland. 2015. Guiding principles for evaluating the impacts of conservation interventions on human well-being. Philosophical Transactions of the Royal Society 370:20150103. http://dx.doi.org/10.1098/ rstb.2015.0103

World Bank. 2005. The World Bank operations manual. World Bank, New York, New York, USA. [online] URL: https://policies. worldbank.org/sites/PPF3/Pages/Manuals/Operational\%20Manual. $\underline{\operatorname{aspx}}$ 
Appendix 1. Table A1.1. Changes in overall subjective well-being over time at the country level.

\begin{tabular}{|c|c|c|c|c|c|c|c|c|c|}
\hline \multirow[t]{3}{*}{ Country } & \multirow{3}{*}{$\begin{array}{l}\text { Intervention } \\
\text { type }\end{array}$} & \multicolumn{4}{|c|}{ A) Better off (yes/no) } & \multicolumn{4}{|c|}{ B) Worse off (yes/no) } \\
\hline & & & Phase 1 & & Phase 2 & & Phase 1 & & Phase 2 \\
\hline & & $\mathrm{N}$ & mean $(\mathrm{SD})$ & $\mathrm{N}$ & mean $(\mathrm{SD})$ & $\mathrm{N}$ & mean $(\mathrm{SD})$ & $\mathrm{N}$ & mean $(\mathrm{SD})$ \\
\hline \multirow{4}{*}{ Global } & none & 1706 & $0.32(0.46)$ & 1901 & $0.34(0.47)$ & 1706 & $0.28(0.45)$ & 1901 & $0.27(0.44)$ \\
\hline & incentives & 774 & $0.43(0.5)^{*}$ & 841 & $0.43(0.49)$ & 774 & $0.28(0.45)$ & 841 & $0.24(0.43)$ \\
\hline & disincentives & 553 & $0.52(0.5)^{*}$ & 697 & $0.47(0.5)^{*}$ & 553 & $0.2(0.4)^{*}$ & 697 & $0.23(0.42)^{*}$ \\
\hline & both & 478 & $0.48(0.5)^{*}$ & 529 & $0.48(0.5)$ & 478 & $0.23(0.42)^{*}$ & 529 & $0.23(0.42)$ \\
\hline \multirow{4}{*}{ Brazil } & none & 160 & $0.61(0.49)$ & 206 & $0.61(0.49)$ & 160 & $0.14(0.35)$ & 206 & $0.14(0.35)$ \\
\hline & incentives & 222 & $0.66(0.48)$ & 235 & $0.62(0.49)$ & 222 & $0.13(0.33)$ & 235 & $0.15(0.36)$ \\
\hline & disincentives & 308 & $0.63(0.48)$ & 418 & $0.56(0.5)$ & 308 & $0.11(0.31)$ & 418 & $0.15(0.36)$ \\
\hline & both & 169 & $0.6(0.49)$ & 188 & $0.61(0.49)$ & 169 & $0.14(0.34)$ & 188 & $0.12(0.33)$ \\
\hline \multirow{4}{*}{ Peru } & none & 90 & $0.31(0.47)$ & 104 & $0.22(0.42)$ & 90 & $0.12(0.33)$ & 104 & $0.18(0.39)$ \\
\hline & incentives & 75 & $0.28(0.45)$ & 90 & $0.27(0.44)$ & 75 & $0.07(0.25)$ & 90 & $0.12(0.33)$ \\
\hline & disincentives & 144 & $0.49(0.5)^{*}$ & 172 & $0.29(0.46)$ & 144 & $0.16(0.37)^{*}$ & 172 & $0.36(0.48)$ \\
\hline & both & 111 & $0.53(0.5)^{*}$ & 128 & $0.34(0.48)$ & 111 & $0.15(0.36)^{*}$ & 128 & $0.28(0.45)$ \\
\hline \multirow{4}{*}{ Cameroon } & none & 116 & $0.3(0.46)$ & 132 & $0.32(0.47)$ & 116 & $0.45(0.5)$ & 132 & $0.44(0.5)$ \\
\hline & incentives & 149 & $0.54(0.5)^{*}$ & 163 & $0.4(0.49)^{*}$ & 149 & $0.37(0.48)$ & 163 & $0.37(0.49)$ \\
\hline & disincentives & 57 & $0.14(0.35)^{*}$ & 61 & $0.39(0.49)^{*}$ & 57 & $0.7(0.46)^{*}$ & 61 & $0.31(0.47)^{*}$ \\
\hline & both & 102 & $0.42(0.5)^{*}$ & 117 & $0.55(0.5)$ & 102 & $0.33(0.47)^{*}$ & 117 & $0.26(0.44)$ \\
\hline \multirow{4}{*}{ Indonesia } & none & 924 & $0.32(0.47)$ & 1013 & $0.36(0.48)$ & 924 & $0.26(0.44)$ & 1013 & $0.21(0.41)$ \\
\hline & incentives & 236 & $0.22(0.42)^{*}$ & 252 & $0.39(0.49)^{*}$ & 236 & $0.39(0.49)^{*}$ & 252 & $0.24(0.43)^{*}$ \\
\hline & disincentives & 23 & $0.48(0.51)$ & 24 & $0.5(0.51)$ & 23 & $0.3(0.47)$ & 24 & $0.29(0.46)$ \\
\hline & both & 43 & $0.37(0.49)$ & 43 & $0.4(0.49)$ & 43 & $0.28(0.45)$ & 43 & $0.3(0.46)$ \\
\hline \multirow{4}{*}{ Tanzania } & none & 238 & $0.13(0.34)$ & 256 & $0.16(0.37)$ & 238 & $0.5(0.5)$ & 256 & $0.41(0.49)$ \\
\hline & incentives & 51 & $0.2(0.4)$ & 56 & $0.27(0.45)$ & 51 & $0.59(0.5)$ & 56 & $0.41(0.5)$ \\
\hline & disincentives & 21 & $0.24(0.44)$ & 22 & $0.36(0.49)$ & 21 & $0.24(0.44)^{*}$ & 22 & $0.32(0.48)$ \\
\hline & both & 53 & $0.19(0.39)$ & 53 & $0.3(0.46)$ & 53 & $0.47(0.5)$ & 53 & $0.34(0.48)$ \\
\hline \multirow[t]{2}{*}{ Vietnam } & none & 178 & $0.3(0.46)$ & 190 & $0.29(0.46)$ & 178 & $0.22(0.42)$ & 190 & $0.41(0.49)$ \\
\hline & incentives & 41 & $0.54(0.5)^{*}$ & 45 & $0.24(0.43)$ & 41 & $0.12(0.33)$ & 45 & $0.31(0.47)$ \\
\hline
\end{tabular}

*Significant differences in the regression models at $\mathrm{p}<0.05$. In the phase 1 column, this symbol indicates a significant difference in the first phase of the research (i.e. baseline) relative to the control group. In the phase 2 column, this symbol shows a significant difference within the group (table line) over time. 